City University of New York (CUNY) CUNY Academic Works

\title{
Latin Nominatives With and Without Verbs
}

Joseph C. M. Davis

CUNY City College

\section{How does access to this work benefit you? Let us know!}

More information about this work at: https://academicworks.cuny.edu/cc_pubs/277

Discover additional works at: https://academicworks.cuny.edu

This work is made publicly available by the City University of New York (CUNY).

Contact: AcademicWorks@cuny.edu 
WORD, 2016

Vol. 62, No. 2, 91-108, http://dx.doi.org/10.1080/00437956.2016.1180000

\title{
Latin nominatives with and without verbs
}

\author{
Joseph Davis* \\ School of Education, The City College of New York, New York, NY, USA \\ (Received 27 January 2016; accepted 22 March 2016)

\begin{abstract}
Although the nominative case has typically been viewed as a syntactic device marking the subject of the verb of a sentence, that case in Latin must instead be understood as a communicative tool operating at the discourse level if its entire distribution is to be accounted for. Attested instances of the Latin nominative case without any verb force this shift. Nominatives with and without verbs alike can be accounted for if concentration of attention at the discourse level is treated as the operative factor. Once the function of the Latin nominative case is properly understood, its distinction from other grammatical morphology (verb forms and demonstrative forms) can be better appreciated. There may be implications for other languages with nominative case morphology that is independent of the verb.
\end{abstract}

Keywords: Nominative; case; Latin; functional grammar; syntax; discourse; demonstrative

\section{The Latin nominative case as a syntactic device}

The presence of the nominative case in Latin has typically been viewed as a sentencelevel phenomenon, both traditionally and in grammars influenced by more modern linguistic scholarship. So it is said that 'The nominative is the case of the subject of the sentence.' This is the typical position even while fundamental exceptions are acknowledged, such as the regular appearance of the nominative case in the construction called the predicate nominative, in dictionary entries, and in the title of a work of literature (Panhuis 1982: v, 71). With the modern formalist redefinition of sentence as essentially a clause (a noun with a verb, embedded or not in a larger sentence), it becomes problematic as well that, in Latin, the subject of an infinitive clause is typically not in the nominative but the accusative case (Chomsky 1982: $140 \mathrm{fn}$. 25). Whether treated at the sentence or the clause level, the nominative in this framework, while morphologically bound to the noun, is syntactically tied to the verb. The manifestation of that link is the putative syntactic agreement (or concord) in grammatical number and person between the subject and the verb.

This assumption that the nominative case is a syntactic device has underlain not only the study of classical Latin itself but too the study of historical change from Latin to the modern Romance languages, whose nouns lack case morphology (e.g. Bauer 1995).

An example consistent with the syntactic view of the nominative case is Example (1), the opening of Caesar's history De bello gallico 'On the Gallic war':

\footnotetext{
*Email: jdavis@ccny.cuny.edu 
(1) Gallia-nom-sg est-sg omnis divisa in partes tres quarum unam incolunt-pl Gaul-nom-sg is-sg all divided into parts three of-which one inhabit- $p l$ Belgae-nom-pl (dbg I:1)

Belgae-nom-pl

'All Gaul is divided into three parts, of which the Belgae inhabit one'

Here, the nominative Gallia is subject of the clause with finite verb est, and both are third-person singular, while the nominative Belgae is subject of the clause with finite verb incolunt, and both are third-person plural. Syntactic agreement obtains, in each clause, between the verb and the noun in the nominative case.

There are, at the same time in the tradition, two additional definitions of subject.

Consistent with one of those definitions, the Belgae in Example (1) are interpretable as the agents of the inhabiting of one part of Gaul, the performers of the action of the verb in that clause. This is the subject as agent of the action of the sentence. Agency is not an issue in the first clause of (1).

According to a third traditional definition of subject, the first clause in (1) would be 'about' Gaul, and the second would be about the Belgae. This is the subject as subject of the thought expressed by the sentence.

All three definitions of subject run concurrently in traditional grammar. Often, they coincide, but often they do not. The three definitions, and the conflicts among them, were pointed out by Diver (1981, incorporated into Diver et al. 2012: 394407). See also Halliday (2004: 57).

\section{The Latin nominative as a tool of communication at the discourse level}

In opposition with this syntactic framework, the nominative case in Latin can be viewed as a communicative tool operating 'with respect to importance of characters at the discourse level', not at the sentence level (Diver \& Davis 2012: 212-19). In this view, the Latin nominative is a signal of the meaning (cf. Saussure's signifiant and signifié) that the writer intends the reader to FOcus his attention at that point in the discourse upon the referent of the lexical item to which the nominative is attached. ${ }^{1}$ Thus the writer can craft a body of discourse in such a way as to keep important parties in FOCUS while relegating less important players to oblique cases or indeed by omitting mention of them altogether. Caesar, as writer, can place the discourse focus upon whomever or whatever he wishes. Rather than being governed by the verb and its morphology, case is instead seen in this way as being communicatively consistent with the verb and its morphology. Case as a tool of communication is seen not as mechanistically driven by syntax, but as expressively conveying the writer's interests, while other elements in the context do so as well.

In (1), for instance, Gallia is put in the nominative case not because it is the subject of the verb est but 'because it is to be the subject of the entire first section of Book I' (Diver 1989: 163). Caesar had other options, among them the option of focusing instead on each of the three parts of Gaul, one by one, not on the region as a whole:

Galliae-gen una-nom pars-nom est ....

Gaul's-gen one-nom part-nom is ....

'One part of Gaul is ....' 
That choice would be accomplished by placing the nominative case not on 'Gaul' but on each 'part' (pars-nom) separately. That, however, would have been a communicatively much less felicitous choice, since the entire first section of Book I is about Gaul as a whole, including the details about how that whole is divided up.

Also infelicitous, if perhaps a bit less so, would have been the option of focusing on the 'three parts' rather than the one whole:

Galliae-gen tres-nom partes-nom sunt ....

Gaul's-gen three-nom parts-nom are....

'The three parts of Gaul are....'

If Caesar had chosen to place FOCUs on the 'three parts', then the grammatical information on the verb too would reflect that choice and would be plural (sunt) rather than singular (est), since the verb is 'About the lexical center to a nearby' nominative (Diver 1989: 163). So at least three things would happen: The nominative case would go on 'parts'; 'Gaul' itself would go into an oblique case; and the grammatical number of the verb would be consistent with the FOCUS on plural 'parts'. Probably too there might be a fourth consequence: the omission altogether of the notion of 'all' or 'whole' (omnis). That choice of FOCUS, however, would not do justice to the overall theme of unity underlying all the division of the country; eventually (Book VII), the peoples do unite against Roman rule.

In sum, Focus considerations at the discourse level have numerous consequences for the grammatical mechanisms employed in a given stretch of text.

\subsection{Quantitative validation at the discourse level}

Discourse-level quantitative evidence supports the hypothesis that the nominative case signals the meaning FOCUS while the ablative, dative, and accusative cases signal NONFOCUS. These two meanings, with their signals, constitute a grammatical system of Focus. The two meanings are, in effect, 'a direction to concentrate attention on something and a direction not to concentrate attention’ (Diver \& Davis 2012: 212). (The genitive case is not part of the Focus hypothesis for Latin.) (See Figure 1).

In the first 15 sections of Book I of De bello gallico, which concerns primarily Caesar and his enemy the Helvetii, these two principal parties skew heavily toward the nominative case, while entities that are mentioned only once in their section skew toward the accusative (Diver \& Davis 2012: 214-15). ${ }^{2}$ Important characters tend to be placed in the nominative case, while unimportant entities tend to be given oblique cases. This skewing is consistent with the hypothesis that the nominative

$\begin{array}{lll}\underline{\text { Semantic substance }} & \underline{\text { meanings }} & \underline{\text { signals }} \\ & \text { FOCUS } & \text { nominative }\end{array}$

Focus

NON-FOCUS ablative, dative, accusative

Diver and Davis (2012: 212)

Figure 1. The Latin System of Focus. 
versus the obliques signals the meaning FOCUS, and it is consistent with the idea that the system of Focus operates at the discourse level. That is, discourse-level considerations of Focus appear to drive a writer's choice of nominative versus oblique case. In a narrative like De bello gallico, those choices often get embedded in actionpacked sentences and so have consequences for lexical choice (choice of verb) and the morphology of grammatical voice (on the verb).

Such claims of topicality, of course, could not be validated at the sentence level, even if Focus were a sentence-level phenomenon. There is no way to know, for instance, given Example (1) in isolation, whether the first clause is 'about' Gaul or instead about the 'three parts', or whether the second clause is about the Belgae or instead about 'one' of the parts of Gaul. Validation of such a claim requires examination of the discourse in which the sentence appears. It requires an independent determination that, for instance, Caesar and the Helvetii are more important in the first 15 sections of Book I of $d b g$ than a minor character such as, say, Castigus of the Sequani.

Focus typically does not remain on the same entity, uninterrupted, through an entire text. Though a text may have an overall theme, such as Caesar versus the Helvetii in Book I of De bello gallico - and this may be reflected statistically - other entities may momentarily take the reader's attention as the discourse is fleshed out. So, in the opening passage of De bello gallico, FOCUs is first placed, (1), with the nominative case, on 'all Gaul' and then successively on each of its three consitituent peoples, the Belgae, the Aquitani, and the Celtae or Galli. Texts will differ in the degree to which one entity stands out above the rest in terms of FOCUS, with perhaps the extreme tendency to be found in a narrative with one principal character or hero.

\subsection{Lack of agreement in number between the nominative subject and the finite verb}

Another difficulty with the traditional idea of the nominative being the case of the subject of the sentence is the observed fact that, at times, the nominative subject does not agree with the finite verb of the clause. The most famous instance of this lack of agreement comes, like (1), from the opening paragraph of Book I of De bello gallico, Example (2):

(2) Gallos ab Aquitanis Garumna-nom. flumen, Gauls from Aquitani Garonne-nom River a Belgis Matrona-nom. et Sequana-nom. dividit-sg. ( $d b g$ I:1) from Belgae Marne-nom and Seine-nom divides 'The Garonne River [divides] the Gauls from the Aquitani; the Marne and the Seine divides [them] from the Belgae.'

Transparently, the syntactic subject of the clause with singular verb dividit is the compound Matrona et Sequana: a lack of concord. But with meaning admitted into the calculus, the reason for the absence of any interpretive problem becomes clear: For one thing, the Marne and the Seine form one boundary which separates the Gauls from the Belgae. Moreover, at the discourse level, it is such features of the geography of Gaul which deserve FOCUs here, consistent with the topic established at the beginning of the section: Gallia-nom est omnis-nom divisa-nom in partes tres 'All Gaul is divided into three parts'.

Another instance of lack of syntactic agreement is Example (3): 
(3) Mittitur-sg ad eos colloquendi causa Gaius-nom Arpineius-nom, eques-nom Is-sent-sg to them of-talking cause Gaius-nom Arpineius-nom, knight-nom Romanus-nom, familiaris-nom Quinti Tituri, et Quintus-nom Iunius-nom Roman-nom friend-nom Quintus Titurius and Quintus-nom Junius-nom ex Hispania quidam, qui iam ante missu Caesaris ad Ambiorigem from Spain certain who already before sending Caesar to Ambiorix ventitare consuerat; $(d b g$ V:27) come-often was-accustomed 'Gaius Arpineius, a Roman knight, a friend of Quintus Titurius, and Quintus Junius, a Spaniard, who had previously been accustomed to go to and fro upon Caesar's errands to Ambiorix, were sent to them for the purpose of a parley' (Loeb) or, more accurately:

'There was sent to them for the purpose of a parley Gaius Arpineius ... and Quintus Junius ....'

The syntactic subject of the clause with singular verb Mittitur is the compound Gaius Arpineius ... et Quintus Iunius: lack of concord. Yet, again, interpretation is consistent with signaled meaning, since the two men were sent as one delegation at the request of the enemy 'for some one of our number to go forth for a parley' uti aliqui ex nostris ad colloquium prodiret (V: 26). And again, Focus is consistent with needs at the discourse level: The enemy asked for a delegation, and one was sent.

See Diver et al. (2012: 401-07) on syntactic concord versus constructio ad sensum, or 'construction according to sense'. Meaning, rather than forcing an exception to the syntax, instead accounts for choices across the board, thus lying behind both frequent and infrequent patterns.

Reid (2011), using English data, argues against syntactic agreement as the linguistic explanation for verb number and in favor of signaled meaning instead. Reid's objection to syntactic agreement as an explanation is both data-based and theoretical. ${ }^{3}$ Though his evidence is limited to English, his argument may well apply to Latin as well and help to account for instances in Latin of both agreement and lack of agreement, both reflecting the communicative needs of the writer.

\subsection{How discourse focus is tied to the clause level}

Although Diver (late author of the Focus hypothesis cited here) clearly viewed Focus, signaled by the nominative case, as a discourse phenomenon, he nevertheless devoted practically all of his analytical efforts to accounting for its distribution in the context of individual finite verbs. Diver was interested in how 'the morphology of the Latin noun or pronoun signals ... how much attention should be paid to the various participants' in the 'events in the narrative' (Diver \& Davis 2012: 211, emphases added). ${ }^{4}$ Thus, someone reading Diver might well forget the discourse matrix of his hypothesis and come away with the false impression that Diver's treatment of the Latin nominative was effectively syntactic, having to do essentially with the grammatical subjects of verbs. 5

But the Focus system is not syntactic. Diver saw the workings of the nominative case in context with the finite verb as a consequence of the Focus system coming, in discourse, into interlock with a separate grammatical system, that of Degree of Control. Four of the cases - nominative, ablative, dative, and accusative - signal 'the relative Degree of Control exercised by a participant over some activity, usually 
that indicated by the verb' (Diver \& Davis 2012: 215, emphasis added). Compare the traditional notion of agency. The four degrees of Control (in context with active verb morphology) are referred to by the simple relative terms MOST, MORE, LESS, LEAST.

Example (4) illustrates:

(4) ipse-nom $\ldots$ se suis copiis-abl suoque exercitu- $a b l$ illis- $d a t$ regna- $a c c$ he-nom self his resources-abl his-and army-abl them-dat kingdoms-acc MOST MORE MORE LESS LEAST conciliaturum confirmat (dbg I:3) to-win pledged 'He pledged himself to win them their kingdoms with his resources and his army'

'He'-nom, Orgetorix, the military leader, would have MOST Control over the winning. He would be enabled in this activity by his 'resources'-abl and his 'army'$a b l$. He would be motivated to undertake this activity by his countrymen, the Helvetii, 'them'-dat, who chose him as their leader. The prize to be won - the pawn - is the Helvetian 'kingdoms'-acc.

It is through this mechanism, this interlock of two grammatical systems, that Focus gets construed with respect to individual events, since the system of Degree of Control has to do with 'characters' roles in individual activities at the clause level'. The 'FocusControl interlock is a useful tool for a writer' because it, 'together with the morphology of the verb, gives the writer a certain flexibility in focusing on participants' (Diver \& Davis 2012: 219). Again, Focus can be placed wherever the writer wishes. And Focus may be signaled even when Degree of Control is not.

Carefully note three crucial points here:

(a) The Focus system is a tool of discourse, not of the sentence or the clause.

(b) The Control system has to do with individual events that are usually - not always - indicated by a verb.

(c) The mechanism whereby writers manipulate Focus on participants in events is the Focus-Control interlock, not the Focus system per se.

These points must be kept in mind as we expand the coverage of data beyond the narrative genre, with its sequence of events and event-participants.

\section{Data expanding the treatment of the nominative case beyond the finite verb}

Diver might be faulted for dwelling too exclusively on the problem of the distribution of the cases in construal with verbs, especially finite verbs. In that way, he gave severely short shrift to instances of the cases, particularly the nominative, in context with non-finite verbs and with no verb at all. But such a piecemeal approach to an analytical problem was in fact typical of Diver. ${ }^{6}$ Moreover, such an approach to a problem was in fact a principled decision. In Diver's view of how linguistic theory ought to proceed, the analyst properly tackles first whatever small problem he can solve and then, using that leverage, expands the scope to larger problems and then even larger problems. In this way, a theory is gradually built up from analytical experience, not devised a priori from speculation and philosophy (Diver [1995] 2012). 
It is past time, then, to examine systematically instances of the Latin nominative case outside of context with finite verbs. In doing so, we can test whether the Focus hypothesis truly accounts for all tokens of the nominative case or whether, instead, such instances constitute counterexamples to the hypothesis or perhaps lie beyond its scope. The conclusion will be that the Focus hypothesis stands, but properly understood as a tool operating at the discourse level, not the clause level.

\subsection{The nominative case with non-finite verbs}

Occasionally, the nominative case is found with a non-finite verb, such as an infinitive, as in Example (5). With infinitives there can be no subject-verb agreement, since the verb form does not mark grammatical person and number.

(5) Interim cotidie Caesar-nom Aeduos frumentum, quod essent publice Meanwhile daily Caesar-nom Aedui corn, which were publicly polliciti, flagitare-inf. (dbg 1:16)

promised, ask-inf

'Meanwhile Caesar was daily pressing the Aedui for the corn that they had promised as a state'. (Loeb)

Were it not for context, the morphology might appear to be random. Discourse, however, reveals the motivation.

Interim cotidie Caesar-nom Aeduos frumentum, quod essent publice polliciti, flagitareinf. ... Diem ex die ducere-inf Aedui-nom: conferri, comportari, adesse dicere-inf. Vbi se diutius duci intellexit-fin ... graviter eos accusat-fin. ...

Tum demum Liscus oratione Caesars adductus, quod antea tacuerat proponit: ( $d b g$ I:16-17). 'Meanwhile Caesar-nom was daily pressing-inf the Aedui for the corn that they had promised as a state. ... Day after day the Aedui-nom delayed-inf: it was being collected, being brought in, was at hand, they said-inf. When he realized-fin that he was being put off too long ... he severely accused-fin them. ...

'Then, and not till then, Liscus-nom, induced by Caesar's remarks, revealed-fin what he previously had concealed-fin: ....' (adapted from Loeb)

There is a standoff between Caesar the Aedui over the provision of corn by the Aedui to the Romans. In the account of this standoff, both parties, Caesar and then the Aedui, appear in Focus, in the nominative case. During the standoff, the frustrated actions of both parties are rendered as infinitives. It is only when the standoff is broken that the decisive actions of both parties are rendered as finite verbs: Caesar 'realized' what was going on and 'accused' the Aedui of stalling, whereupon one of them, Liscus, finally 'revealed' the true reason for the breach of contract. According to a separate hypothesis (Diver \& Davis 2012: 197 fn. 4), finite verbs rank higher than non-finites in 'Vividness' or 'attentionworthiness' of the action. So, in this passage, the reader's FOCUS (nominative case) oscillates between the parties of the standoff, but his attention to the events in the narrative increases when the standoff is resolved.

There would appear to be no reason to abandon the Focus hypothesis for the nominative case just because the verb is not finite and cannot therefore exhibit agreement. 


\subsection{The nominative case with no verb}

At times, too, the nominative case is found with no verb at all. According to traditional grammars (e.g. Allen \& Greenough §319), this happens 'very commonly' 7 In Cicero's essay De senectute 'On old age', I find 21 examples of verbless nominatives in 46 pages of text.

Several of those examples in Cicero can be classified as instances of ellipsis, such as (6):

(6) Sed redeo ad me. Quartum ago annum et octogesimum: vellem but I-return to me. Fourth I-make year and eightieth: I-would forequidem idem posse gloriari quod Cyrus-nom, sed tamen hoc queo dicere, .... (ds 32)

my-part same could boast as Cyrus-nom, but yet this I-can say 'But I return to myself. I am eighty-four; would that I could boast as Cyrus-nom [boasted]; but still I can say this:

The shift of Focus onto Cyrus here, with the nominative case, is justified. In the preceding context, the speaker (a putative Cato) has reported: 'Cyrus-nom, in Xenophon, in that discourse which he delivered when he was very old and on his deathbed, says that he had never felt that his old age was any less vigorous than his youth had been. I-nom (ego) remember that as a boy-nom ...' (adapted from Loeb). Then comes Example (6). Then, immediately following (6), the speaker says 'while I am not now, indeed, possessed of that physical strength which I had as a private solder in the Punic War ..., yet, as you see, old age has not quite unnerved or shattered me' (Loeb). Thus, the speaker, by using the nominative case, places himself and Cyrus on comparable planes of FOCUS. It is another matter entirely that no explicit verb is needed in Example (6) to make it clear that Cyrus boasted.

In other examples, the general nature of the activity is easily inferred from context even if, strictly speaking, there is no ellipsis of a verb that has some form actually present in the nearby context. Such is (7):

(7) Sed quid ego-nom alios? Ad me ipsum iam revertar. ( $d s$ 45) but why I-nom others? To me same now I-shall-return

But why [should] I-nom [discuss?] others? Let me now return to myself.

In the extended context, Cato has been portrayed as discussing at length his own experience with old age; indeed, such constitutes the bulk of this Ciceronean work. In the immediately preceding context, Cato has reported upon the old-age activities of a certain Gaius Duellius. It is therefore easy to infer that here, when Cicero has Cato say ego alios 'I-nom others-acc', with no verb, the activity suggested is that of a discussion or treatment. There is no need to abandon the Focus hypothesis for the nominative case just because there is no overt verb here. Focus continues on the first-person Cato, as it has so often through the essay. That continuation, in fact, is confirmed immediately by the first-person verb revertar 'I-shall-return'.

Similarly superfluous would be a verb of speaking when the nominative is used to identify a speaker in a dialogue, as repeatedly in Example (8): 
(8) II. Scipio-nom. Saepe numero admirari soleo cum hoc C. Laelio cum ceterarum rerum tuam excellentem, M. Cato, ... .

CАто-nom. Rem haud sane, Scipio et Laeli,....

...

Laelius-nom. Atqui, Cato, .... .

CATO-nom. Faciam vero, Laeli,....

LAelius-nom. Volumus sane, nisi molestum est. Cato, ...

III. CATO-nom. Faciam ut potero, Laeli....

LAelius-nom. Est, ut dicis, Cato; .... .

CATO-nom. Est istuc quidem, Laeli, aliquid .... ( $d s$ 4-8)

II. ScIPIO-nom. When conversing with Gaius Laelius here present, I am frequently wont to marvel, Cato....

CATO-nom. I think, my friends, that....

...

Laelius-nom. True, Cato, .... .

CATO-nom. To be sure, I will, Laelius, .... .

LAELIUS-nom. Unless it is too much trouble to you, Cato, .... .

III. CATO-nom. I will do so, Laelius, .... .

LAELIUS-nom. What you say is true, Cato; .... .

CATO-nom. There is something in that objection, Laelius (Loeb)

The context of a dialogue makes it clear that each person identified in the nominative case speaks the following words. Indeed, the dialogue was introduced explicitly: 'I have ascribed [the discourse] to the venerable Marcus Cato; and I represent Laelius and Scipio, while at his house, expressing wonder that he bears his age so well, and Cato replying to them' (Loeb). The reader's FOCUs shifts from one participant in the dialogue to another. There is no need to abandon the Focus hypothesis.

In the following example, from Caesar's De bello gallico, it is the very wide discourse context that supports the hypothesis that the reader's FOCUs is, indeed, to be on the referent of the word in the nominative case, 'island', even in the absence of a verb.

(9) Insula-nom natura triquetra-nom, cuius unum latus est contra Galliam (dbg V:13) island-nom nature triangular-nom, whose one side is opposite Gaul 'The island [is] by nature triangular, of which one side is opposite Gaul'.

The example comes from Book V, on Caesar's second campaign for Britain. There is much about Britain in this section; the island certainly deserves FOCUS at the introduction of the section. The section goes on to describe the geography of the island. For Caesar, of course, the important point to make about that geography is that one side 'is' opposite Gaul.

Notice that the second clause, having to do with the 'side' facing Gaul - despite the fact that traditional grammar labels this a subordinate clause - has a finite verb, est. By contrast, the beginning of the sentence, having to do with the overall shape of the island, merits no verb at all. Recall the Vividness hypothesis: Finite verbs in Latin (e.g. est 'is') rank relatively high on that scale, which ranges down through the infinitives and participles. Among the various verb forms, the finites, especially with active form, indicate points of relative importance in the narrative. Literally off the scale, effectively lower in importance even than events mentioned as participles, are stretches 
of discourse that merit no verb at all, such as the first half of Example (9) (cf. Diver \& Davis 2012: 195). To Caesar, it is more important that one side of Great Britain 'is opposite' (est contra) Gaul than that the island is triangular.

Contrast the absence of verb just seen in Example (9)'s Insula natura triquetra 'The island [is] by nature triangular' with the presence of finite verb est in Example (1): Gallia est omnis divisa in partes tres 'All Gaul is divided into three parts'. It stands to reason that, in a history of Caesar's war against the nations of Gaul, the fact that Gaul is divided into three parts, with three peoples, should rank higher in importance than the fact that the island of Great Britain has three coasts. In both examples, (1) and (9), FOCUS is placed by the nominative case on a geographical region, but only in Example (1) is the description of the region important enough to merit verb est.

Example (9) is perhaps the only example in Caesar's De bello gallico of a nominative with no verb at all. The scarcity of verbless nominatives in that text, relative to Cicero's essay, makes sense when we realize that De bello gallico is essentially an action-adventure story, with one event following closely upon the heels of another. A heavy reliance upon the narrative genre might give a skewed impression of the distribution of the nominative, might make one cling to the syntactic view of the nominative as tied to the verb of a clause. A more accurate impression of the distribution of the nominative is gained with a wider study of the nominative in discourse of various genres.

Like discourse context, situational context can support an inference of some type of activity that need not be named explicitly in order for the referent in the nominative case to be interpreted as focus-worthy. Such is Example (10), the full text from a firstcentury AD funerary monument. (Forward slash here indicates a line break in the text on the monument. Some Latin words are abbreviated on the monument. The text in square brackets has been interpolated by the Museum.)

(10) DIIS MANIB / ANTHI-gen / L.IVLIVS-nom GAMVS-nom PATER-nom FIL gods dead / Anthus-gen / L. Iulius-nom Gamus-nom father-nom son DVLCISSIM (Metropolitan Museum of Art, New York) sweetest 'To the spirits of the dead / Of Anthus / L. Julius Gamus, father [made this for his] sweetest son'

The wall text provided by the Museum offers context for the viewer:

The front of the altar is carved in high relief with the figure of the deceased, named in the accompanying, elegantly carved Latin inscription as Anthus. The altar was set up by his father, L(ucius) Iulius Gamus. Although Anthus' age is not given, he clearly died while still a child, since he is referred to as '(his) sweetest son', and a personal touch is given to the relief by showing Anthus with his pet dog.

The combination of the discourse context and the situational context makes it clear that the monument exists in memory of a deceased boy named Anthus (oblique case), and that his father, L. Iulius Gamus (nominative case), made the monument.

The Focus hypothesis can be applied here if we admit the 'human factor' that Diver viewed as being necessary for the analyst's account of the observed distribution of forms in natural usage (Diver [1995] 2012: 485-86 et passim). One well-known 
aspect of human intelligence is egocentricity. And so here, even though the monument literally depicts the boy Anthus, the monument's text signals that its reader's FOCUS should be on the surviving person who paid for the monument, directed its construction, and determined its inscription: the father, L. Iulius Gamus, whose name is given in the nominative case.

Although the name of the dedicatee may, as in (10), appear in an oblique case, it may also appear in the nominative, as in (11):

\section{(11) C. VIBIVS-nom / HEROSTRATVS-nom / VIBIA-nom C.L. / HAERESIS-nom (Metropolitan Museum of Art, New York) \\ C Vibius-nom / Herostratus-nom / Vibia-nom C.L / Haeresis-nom 'C. Vibius Herostratus, Vibia C. L. Haeresis'}

This is the text from a monument to two individuals, both of whose names appear in the nominative case. Here no benefactor is mentioned, and no activity need even be inferred. With no benefactor's egocentricity at stake, the reader's FOCUS is free to settle upon the two deceased.

\subsection{Other cases without verbs}

Not only the nominative, but the other cases as well appear sometimes without verbs. Example (7), above, contains an accusative, alios 'others', with no verb. Example (9) contains an ablative, natura 'nature', with no verb. Example (10) contains a genitive, Anthi 'Anthus', with no verb. Datives with no verb appear in the following, Example (12), the inscription on another marble funerary altar:

(12) DIS-dat MANIBVS-dat / COMINIAE-dat .TYCHE.SANCTISSIMAE-dat /

gods-dat dead-dat / Cominia-dat Tyche saintliest-dat /
L.ANNIVS-nom FESTVS-nom.CONIVGI-dat / CASTISSIMAE-dat
L. Annius-nom Festus-nom wife-dat / most-chaste-dat
SIBIQ-dat AMANTISSI / MAE-dat VIXIT ANNIS-abl XXVII /
him-dat most-loving- /-dat lived years-abl $27 /$
MENSIBVS-abl XI DIEBVS-abl XXVIII / ET SIBI-dat
months-abl 11 days-abl $28 \quad$ / and himself-dat
POSTERISQ-dat SVIS-dat (Metropolitan Museum of Art, New York)
descendants-dat-and his-dat

A translation is provided by the Museum, with verb bracketed by the Museum:

'To the spirits of the dead. Lucius Annius Festus [set this up] for the most saintly Cominia Tyche, his most chaste and loving wife, who lived 27 years, 11 months, and 28 days, and also for himself and for his descendants'.

The phrase dis manibus 'to the spirits of the dead' is formulaic, appearing on several of the monuments in the gallery. The other datives are peculiar to this monument; they name and characterize the individuals who motivated - and thus to some degree controlled - L. Annius Festus (nominative) to set the monument up: 'the most saintly Cominia Tyche, most chaste and loving wife', 'himself', and 'his descendants'. 
Traditional grammars recognize uses of the oblique cases without verbs. The ablative case outside the syntax of the sentence is well known as the ablative absolute. Allen \& Greenough note too: the 'Adverbial Accusative' and the accusative 'in Exclamations' (\$397); the 'Genitive of Exclamation' (\$359); the 'Dative of Reference' (\$379) and the dative with adjectives or adverbs, with or without a verb present (\$384).

With the data set expanded beyond the action-adventure narrative of De bello gallico, the hypothesis of Degree of Control, like the hypothesis of Focus, must be interpreted as non-syntactic. We have seen that the system of Focus (signaled by the nominative versus the ablative, dative, and accusative) must be understood as a discourse-level phenomenon. Now we see why Diver said (quoted above) that Degree of Control has to do with control 'exercised by a participant over some activity, usually that indicated by the verb': the presence of a verb is not crucial for the Control meaning to be signaled. Even though Control may operate on a more local level than Focus - typically at the level of the clause rather than that of the discourse - Control should not be thought of as syntactic in the sense that its signaling mechanism (the cases) is tied in any way to a verb. The semantic substance of Degree of Control can be signaled by the cases alone, without any verb being explicitly present in the text.

\subsection{Verbs with no nominative}

It is widely known that, in Latin (as in some modern Romance languages), finite verbs often appear with no overt subject, that is, with no word in the nominative case. This is so widespread as hardly to need exemplification here; if need be, note redeo 'I-return' in Example (6) and vixit 'she-lived' in (12). The first instance of many in De bello gallico appears in the work's opening paragraph, given here as Example (13):

(13) propterea quod a culta atque humanitate provinciae longissime therefore because from culture and civilization province farthest absunt ( $d b g$ I:1)

are-away- $p l$

'because they are farthest removed from the culture and the civilization of the Province' (Loeb)

The immediately preceding context makes clear just who 'are farthest removed':

Horum omnium fortissimi sunt Belgae ( $d b g \mathrm{I}: 1)$

these all bravest are Belgae

'Of all these, the bravest are the Belgae'

In principle, the reliance upon context for a full interpretation is no different in instances of the nominative without a verb, as in Examples (6)-(12), than it is here, where we find a verb without a nominative. Morphologically too, the two situations are comparable, since both the noun or pronoun with nominative case and the finite verb provide information as to grammatical person and number. Perhaps the construction verb-without-nominative may be more common in usage - and therefore so familiar - only because the nature of most discourse is to dwell upon one or a few 
individuals who perform a variety of acts, rather than to dwell upon one event that is performed by a variety of individuals. As a consequence, in most discourse, implicit subjects are more easily inferred than implicit verbs. For instance, it is fairly easy to infer, in De bello gallico, that the subject of a third-person singular verb is Caesar; it is more unexpected - though hardly unmanageable - to infer, in De senectute, that Cato, in his monologue, is reporting different events of speaking by sequentially different speakers.

The problem of the distribution of the nominative case in Latin is a separate problem from the distribution of the finite verb in Latin.

\section{Various grammatical systems of attention, and the differences among them}

Over the years, Diver posited three distinct grammatical systems for Latin having to do with concentration of attention: the system of Vividness satellite to the verb stem (seen above), the system of Focus satellite to the noun stem (also seen above), and a system that is not satellite to either the verb stem or the noun stem: a system that he called Deixis, or Concentration of Attention (Diver [ca. 1970] 2012); this comprised the pronouns (also used as adjectives) traditionally known as demonstratives. In addition, he posited for Homeric Greek similar systems to these plus a system unique to Greek, that of Sharpness of Focus, which had to do with the opposition in that language between accusative and genitive satellite to the noun (Diver [1978] 2012: 128-30). ${ }^{9}$ Diver saw in this proliferation of attention systems something that reflected quite well his conviction that language is a tool of communication shaped in quite essential ways by very human abilities and needs, the 'human factor' (Diver \& Davis 2012: 195).

In an unpublished manuscript, Diver (1984: 51) said explicitly that the substance of Deixis (the demonstratives) is 'the same basic substance' as that of Focus and Sharpness of Focus. ${ }^{10}$ He went on to suggest - albeit in just a few passing phrases - how their evidently quite different exploitations in usage might be grounded in the apparatus of the grammar. The differences can be seen 'most obviously in respect to satellite relation'. The systems of Focus (in Latin and Greek) and Sharpness of Focus (in Greek) are satellite to a noun (or pronoun or adjective) stem. In the system of Deixis, on the other hand, there is 'no satellite relation' and so 'the meanings [of the system] do not automatically provide information [directly] about the referent of a particular Lexical Item'. In other words, the Latin system of Focus, signaled by the cases, is both morphologically and semantically linked to the noun stem (e.g. Galli-a of Example (1)), while the system of Deixis, signaled by the demonstratives (e.g. ips'he' of Example (4)), is free-floating. Consequently, attention is directed by the two systems onto different communicative problems. (Both systems also involve signals of grammatical number and gender.)

The profound consequences of differences in satellite relation and degrees of interlock of semantic substances were only dimly appreciated when Diver wrote the texts cited here. Those consequences came to be more fully appreciated with the exploration of the nature of an opposition of substance such as that between Italian egli 'he' and lui 'he, him' both of which have meanings of grammatical sex, number, and deixis, but only one of which (egli) also has a meaning of grammatical Focus (Davis 1992). Those consequences were further explored with the study of the Italian disjunctive 


\begin{tabular}{lll} 
Semantic substance & meanings & $\underline{\text { signals }}$ \\
\cline { 2 - 3 } & D1 & ipse \\
& D2 & hic \\
Concentration & D3 & iste \\
of Attention & D4 & ille \\
(Deixis) & D5 & is \\
& D6 & se
\end{tabular}

(Diver [ca. 1970] 2012: 267)

Figure 2. The Latin System of Deixis.

pronouns essi (with both gender and number), loro (with number only), and sé (with neither) (Davis 2002) and of the Serbo-Croatian clitic pronouns (Gorup 2006).

Figure 2 gives Diver's hypothesis for the Latin system of Deixis, or Concentration of Attention. The notations D1-D6, for the signaled meanings of the system, indicate relative positions on a scale from highest to lowest attention. The signals of the system (ipse ... se) are given in masculine singular citation form.

In the unpublished manuscript, Diver claimed that the system of Deixis had two uses. For one, Deixis is 'commonly used ... to instruct the hearer [or reader] to concentrate his attention on some aspect of the problem of interpretation of the message'. The text that follows this cryptic statement makes a bit more clear what Diver meant.

By the phrase 'concentrate ... attention on some aspect of the problem of interpretation of the message', Diver evidently intended the common use of these forms for 'Referent Search', akin to a usage of English this and that. This point is developed in Diver ([1992] 2012). It can be illustrated fairly succinctly by three of the signals of Deixis in the opening passage of De bello gallico, Example (14) (parts of which have been seen above):

(14) Gallia est omnis divisa in partes tres, quarum unam incolunt Belgae, aliam Aquitani, tertiam qui ipsorum lingua Celtae, nostra Galli appellantur. $\mathrm{Hi}$ omnes lingua, institutis, legibus inter se differunt. Gallos ab Aquitanis Garumna flumen, a Belgis Matrona et Sequana dividit. Horum omnium fortissimi sunt Belgae, propterea quod a culta atque humanitate provinciae longissime absunt, minimeque ad eos mercatores saepe commeant atque ea quae ad effeminandos animos pertinent important ( $d b g$ I: 1$)$

'All Gaul is divided into three parts, of which the Belgae inhabit one, the Aquitani another, and the third those who in their own language are called Celts, in ours Gauls. These ( $\mathrm{Hi}$ ) all differ among one another (se) in language, customs, and laws. Of them (Horum) all, the bravest are the Belgae, because they are farthest away from the culture and the civilization of the Province [of Rome], and least often do merchants visit them (eos) and bring things (ea) which lead to effeminacy'

A relatively high level of Deixis, D2 ( $h i$ and horum, forms of hic), is used to instruct the reader to search for a referent, which turns out to be the collection of all three peoples named in the first sentence. All three of those have to be conceptually 
united if the referent of hilhorum is to be correctly identified. By contrast, a relatively low level of Deixis, D5 (eos, a form of is), is used to instruct the reader to search for a referent which turns out to be just one of the peoples: the Belgae, who were just mentioned in an earlier clause of the same sentence. And that same relatively low level of Deixis ( $e a$, also a form of $i s)$ is used to instruct the reader to search for a referent which turns out to be scarcely worth bothering with, since it is never explicitly named but left vague ('things'). Finally, the lowest level of Deixis, D6 (se), is used to instruct the reader that the referent is most easily identified: it is indeed the same as the referent of $h i$ and of the third-person ending of the verb differunt 'differ'.

The other use of Deixis, said Diver, is to 'provide information about the referent of a particular Lexical Item'. By this, Diver evidently intended the use of the highly deictic forms (particularly ipse) for 'emphasis'. He gave one example:

(15) paene ab ipso vallo portisque castrorum barbaros avertisset ( $d b g$ VI:42) almost from very rampart gates-and camp natives turned-away-3-sg 'she (fortune) had turned away the natives almost from the very rampart and gates of the camp'

Note the explicit presence of the lexical item vallo 'rampart', which has the same referent here as ipso; there is no problem of referent-finding.

Another instance can be found in Example (7), repeated here as (16):

(16) Sed quid ego alios? Ad me ipsum iam revertar. (ds 45) but why I others? To me same now I-shall-return But why [should] I [discuss?] others? Let me now return to myself.

Note the explicit presence of me 'me', which has the same referent here as ipsum.

In the context surrounding Example (15), Caesar is aghast that, in his absence, the Romans have allowed the Germans to advance almost all the way into the Roman camp, when, in Caesar's view 'no room should have been left for even the slightest mischance' (Loeb). Thus, one can justifiably say that there is 'emphasis' on vallo 'gate'. In (16), Cicero has Cato contrasting himself with alios 'others; thus, one can say that there is emphasis on me 'me'.

However, it seems possible to view even such examples as instructions to 'the hearer [or reader] to concentrate his attention on some aspect of the problem of interpretation of the message'. In this way, all the examples of the signals of Deixis illustrate essentially the same process of interpretation on the basis of grammatical meaning. So the particular 'aspect of the problem of interpretation of the message' that causes relative difficulty in Example (15) might well be the occurrence, entirely contrary to Caesar's expectation, that the Germans should advance all the way to the Roman rampart. In (16), the interpretive problem might be that the speaker is abruptly changing topics, from others back to himself. Each of these, it would seem, can be viewed as some 'problem of interpretation of the message'.

If so, then the difference between the systems of Focus and Deixis can be fairly succinctly stated: The system of Focus (the cases) directs attention onto the known referent of some lexical item; that referent must be important in the discourse. The system of Deixis (the demonstratives) directs attention but not necessarily to any known 
referent; perhaps the referent needs to be identified, or perhaps there is some other interpretive problem that needs to be solved if the discourse is to be correctly processed.

Of course, the details of the mechanisms whereby the two (or three, including Sharpness of Focus) systems direct attention remain to be worked out; Diver's remarks were only suggestive. But meanwhile it appears that, for instance, the highly demonstrative yet oblique ipso of (15) is not a contradiction (Concentrate attention and do not concentrate attention). Rather, that ipso may be a highly precise configuration of communicative machinery: Concentrate attention, as there is some interpretive problem (Deixis); and yet, do not concentrate attention on that referent, because some other referent is more attentionworthy in the discourse (Focus). Such a line of reasoning might well prove to be productive if a detailed analysis of actually occurring discourse data were fully carried out. It might even turn out that the two systems do not, after all, have to do with 'the same basic substance' but with two semantic substances that differ in subtle but important ways. There might also be implications for the analysis of other languages that have case morphology which is separate from the verb, such as German (Zubin 1979) and Serbo-Croatian (Gorup, personal communication).

\section{Conclusion}

The hypothesis of FOCUS for the Latin nominative case appears to hold when the data set is extended beyond nominatives that occur with a finite verb. The Latin nominative case is a communicative tool of discourse, directing attention toward the referent of the word to which the case ending is attached, whether that appears in context with a finite verb, a non-finite verb, or no verb at all. Latin has other grammatical systems for directing attention in other ways. The differences among the systems have to do, at least in part, with rather transparent differences in morphological satellite structure between stem and affix.

\section{Disclosure statement}

No potential conflict of interest was reported by the author.

\section{Notes}

1. Here the convention is to indicate formally hypothesized linguistic (i.e. signaled) meanings in all capital letters, names of semantic substances with initial capital.

2. The numbers are: Frequent mention, nominative 124; frequent mention, accusative 23; rare mention, nominative 28; rare mention, accusative 105; odds ratio 20 .

3. This important theoretical argument against agreement as a linguistic reality holds here even though the details of Latin and English are quite different; specifically, the signals of Focus in English are, unlike the Latin cases, very much tied to the verb, since English has not noun cases but positional signaling (word order) centered around the verb.

4. Diver's earliest interest was in the history of Indo-European languages, including Latin, as reflected in Diver $(1955,1958)$.

5. Such might be the impression upon reading the brief summary of Diver's Focus hypothesis in Huffman (2001: 43-44). Diver's students posited Focus systems in several languages, but in most of these - not in German - the signaling mechanisms are indeed, unlike Latin, morphologically tied to the verb: Garcia (1975) for Spanish clitics, Zubin (1979) for German 
case, Gilden (1989) for French word order, Davis (1995) for Italian clitics, Huffman (1997) for French clitics, and Reid (1991, 2011) for English word order. Contini-Morava (2011) discusses Reid (2011), including the ambiguity in his treatment as to whether Focus for him in English is a phenomenon of discourse or of the lexical verb. Thus, the question of the status of Focus in Latin for Diver has consequences.

6. In an earlier (ca. 1982) treatment of the Latin cases (mentioned in the 'Introduction' to Diver \& Davis 2012), Diver had ignored entirely the deponent verbs, achieving thereby what looked like a successful solution to the problem of the distribution of the cases: a scale of Degree of Control with two 'phases', one for Degree of Control in construal with active verbs (as in Example 4) and another for Degree of Control in construal with passive verbs. It was only later (ca. 1995) that Diver grappled with the distribution of the cases with respect to all verbs - active, passive, and deponent - and so radically revised his hypothesis.

7. Except that Allen and Greenough ([1888] 2001) consider this to be an instance of omission of the verb.

8. See Huffman (1997) on a participant's motivation as a factor in a writer's choice of Degree of Control.

9. Diver developed these hypotheses for his classes at Columbia University and wrote them up in the series Columbia University Working Papers in Linguistics, but they were not formally published until the posthumous appearance of his collected works (Huffman \& Davis 2012).

10. Although this document is clearly marked 'For class use only', I choose, given my urgent need for this idea, to interpret the admonition as a caveat rather than a prohibition.

\section{References}

Allen, J. H. \& J. B. Greenough. [1888] 2001. Allen and Greenough's new Latin grammar for schools and colleges: Founded on comparative grammar. Ed. J. B. Greenough, G. L. Kittredge, A. A. Howard \& B. L. D'Ooge, Updated by Anne Mahoney. Newburyport, MA: Focus Publishing/R. Pullins.

Bauer, Brigitte L. M. 1995. The emergence and development of SVO patterning in Latin and French: Diachronic and psycholinguistic perspectives. New York: Oxford University Press.

Chomsky, Noam. 1982. Lectures on government and binding: The Pisa lectures. Dordrecht: Foris.

Contini-Morava, Ellen. 2011. And now for something completely different: Reid on English verb number. Natural Language and Linguistic Theory (Topic/Comment Special: PhiFeature Inflection and Agreement) 29. 1147-62.

Davis, Joseph. 1992. Italian egli and lui: Grammatical meaning and inference. New York: Columbia University PhD dissertation. UMI 9313892.

Davis, Joseph. 1995. The linguistic sign as unifying principle behind syntactic peculiarities: The Italian clitic ne. CLS 31: Papers from the 31st Regional Meeting of the Chicago Linguistic Society. Vol. 2: The parasession on clitics. 79-90.

Davis, Joseph. 2002. A surpassingly simple analysis. In Wallis Reid, Ricardo Otheguy \& Nancy Stern (eds.), Signal, meaning, and message, 113-36. Amsterdam/Philadelphia: John Benjamins.

Diver, William. 1955. The problem of Old Bulgarian $\check{s} t^{\prime}$. WORD 11. 228-36.

Diver, William. 1958. On the prehistory of Greek consontantism. WORD 14(1). 1-25.

Diver, William. [ca. 1970] 2012. Avoidance of the obvious: The pronoun as a minimax solution. In Alan Huffman \& Joseph Davis (eds.), Language: Communication and human behavior. The linguistic essays of William Diver, 247-63. Leiden/Boston: Brill.

Diver, William. [1978] 2012. Putting the horse before the cart: Linguistic analysis and linguistic theory. In Alan Huffman \& Joseph Davis (eds.), Language: Communication and human behavior. The linguistic essays of William Diver, 101-33. Leiden/Boston: Brill.

Diver, William. 1981. On defining the discipline. Columbia University working papers in linguistics 6. 59-117.

Diver, William. 1984. The grammars of Homeric Greek and Classical Latin. Unpublished MS. Department of Linguistics, Columbia University. Various versions for class use.

Diver, William. 1989. Latin primer. Columbia University working papers in linguistics 10. 155242. 
Diver, William. [1992] 2012. The Latin demonstratives. In Alan Huffman \& Joseph Davis (eds.), Language: Communication and human behavior. The linguistic essays of William Diver, 26577. Leiden/Boston: Brill.

Diver, William. [1995] 2012. Theory. In Alan Huffman \& Joseph Davis (eds.), Language: Communication and human behavior. The linguistic essays of William Diver, 445-519. Leiden/Boston: Brill.

Diver, William \& Joseph Davis. 2012. Latin voice and case. In Alan Huffman \& Joseph Davis (eds.), Language: Communication and human behavior. The linguistic essays of William Diver, 195-245. Leiden/Boston: Brill.

Diver, William, Joseph Davis \& Wallis Reid. 2012. Traditional grammar and its legacy in twentieth-century linguistics. In Alan Huffman \& Joseph Davis (eds.), Language: Communication and human behavior. The linguistic essays of William Diver, 371-443. Leiden/Boston: Brill.

García, Erica C. 1975. The role of theory in linguistic analysis. Amsterdam: North-Holland.

Gildin, Bonny L. 1989. Subject order in French: A signal-meaning analysis. PhD dissertation. UMI 9005873. New York: Columbia University.

Gorup, Radmila. 2006. Se without deixis. In Joseph Davis, Radmila J. Gorup \& Nancy Stern (eds.), Advances in functional linguistics: Columbia School beyond its origins, 95-209. Amsterdam/Philadelphia: John Benjamins.

Halliday, M. A. K. 2004. An introduction to functional grammar. 3rd edn, revised by Christian M. I. M. Matthiessen. London: Arnold.

Huffman, Alan. 1997. The categories of grammar: French lui and le. Amsterdam/Philadelphia: John Benjamins.

Huffman, Alan. 2001. The linguistics of William Diver and the Columbia School. WORD 52(1). $29-68$.

Huffman, Alan \& Joseph Davis (eds.). 2012. Language: Communication and human behavior. The linguistic essays of William Diver. Leiden/Boston: Brill.

Panhuis, Dirk G. J. 1982. Communicative perspective in the sentence: A study of Latin word order. Amsterdam / Philadelphia: John Benjamins.

Reid, Wallis. 1991. Verb and noun number in English: A functional explanation. London: Longman.

Reid, Wallis. 2011. The communicative function of English verb number. Natural Language and Linguistic Theory 29. 1087-146.

Zubin, David. 1979. Discourse function of morphology: The focus system in German. In Talmy Givón \& C. Li (eds.), Syntax and semantics 12: Discourse and syntax, 469-504. New York: Academic. 